\title{
BIODIVERSITY AND ADULT EMERGENCE PERIODS OF MAYFLIES (EPHEMEROPTERA) INHABITING CANDLE LAKE, SK
}

DALE PARKER, AquaTax Consulting, 1204 Main Street, Saskatoon, SK, S7H OL2, E-mail: <dale.parker@sasktel.net>; RON HLASNY, Saskatchewan Environment, Resource Stewardship, 800 Central Avenue, Prince Albert, SK, S6V 6G1; JEFF WEBB, Department of Environmental Management \& Ecology, Albury-Wodonga Campus, PO Box 821, Wodonga, Victoria, Australia, 3689

\section{Introduction}

Over two-thirds of Saskatchewan's freshwater is found in lakes and rivers of the boreal forest. ${ }^{6}$ These habitats not only provide a reservoir of freshwater but also offer economic opportunities for fishing, trapping, hunting, recreation, and ecotourism. ${ }^{6}$ However, such activities can adversely affect these habitats through excessive use and pollution. Watershed usages such as logging, mining, and agriculture, and the effects of climate change can also affect the physical, chemical and biological integrity of these boreal aquatic ecosystems. ${ }^{14}$ Detailed baseline data on the biodiversity, biology and ecology of aquatic animals inhabiting lakes and rivers provide an understanding of how these systems function and facilitate accurate monitoring procedures. ${ }^{13}$

Mayflies (Ephemeroptera) form a significant part of Saskatchewan's aquatic insect diversity. ${ }^{11,16}$ Of the 675 mayfly species reported in North America, 106 are known from Saskatchewan. ${ }^{16,17}$ As larvae, mayflies form important basic links in aquatic food webs by feeding on algae and decaying organic material. ${ }^{5,10,12}$ The larvae and adults are also important prey for fish, waterfowl, passerine birds, bats and predatory insects. 5,16 Many mayfly species are intolerant to pollutants, low oxygen levels and habitat alterations, and for these reasons are often used in environmental impact assessments and monitoring programs. ${ }^{7,12,13,16}$ Unfortunately, biological information regarding most Saskatchewan mayflies is lacking. ${ }^{16}$ This paper reports on mayflies collected from Candle Lake, Saskatchewan during research conducted in 2001 and 2002.

\section{Study Area}

Candle Lake is located in central Saskatchewan on the southern edge of the boreal forest (Figure 1). The lake covers an area of 13,252 hectares and has a maximum depth of 18.5 meters. The resort village of Candle Lake, associated subdivisions, cabin developments, marinas and a provincial park are found adjacent to the lake. A large number of people visit the lake for a variety of year round recreational activities. Land use in the Candle Lake watershed includes 


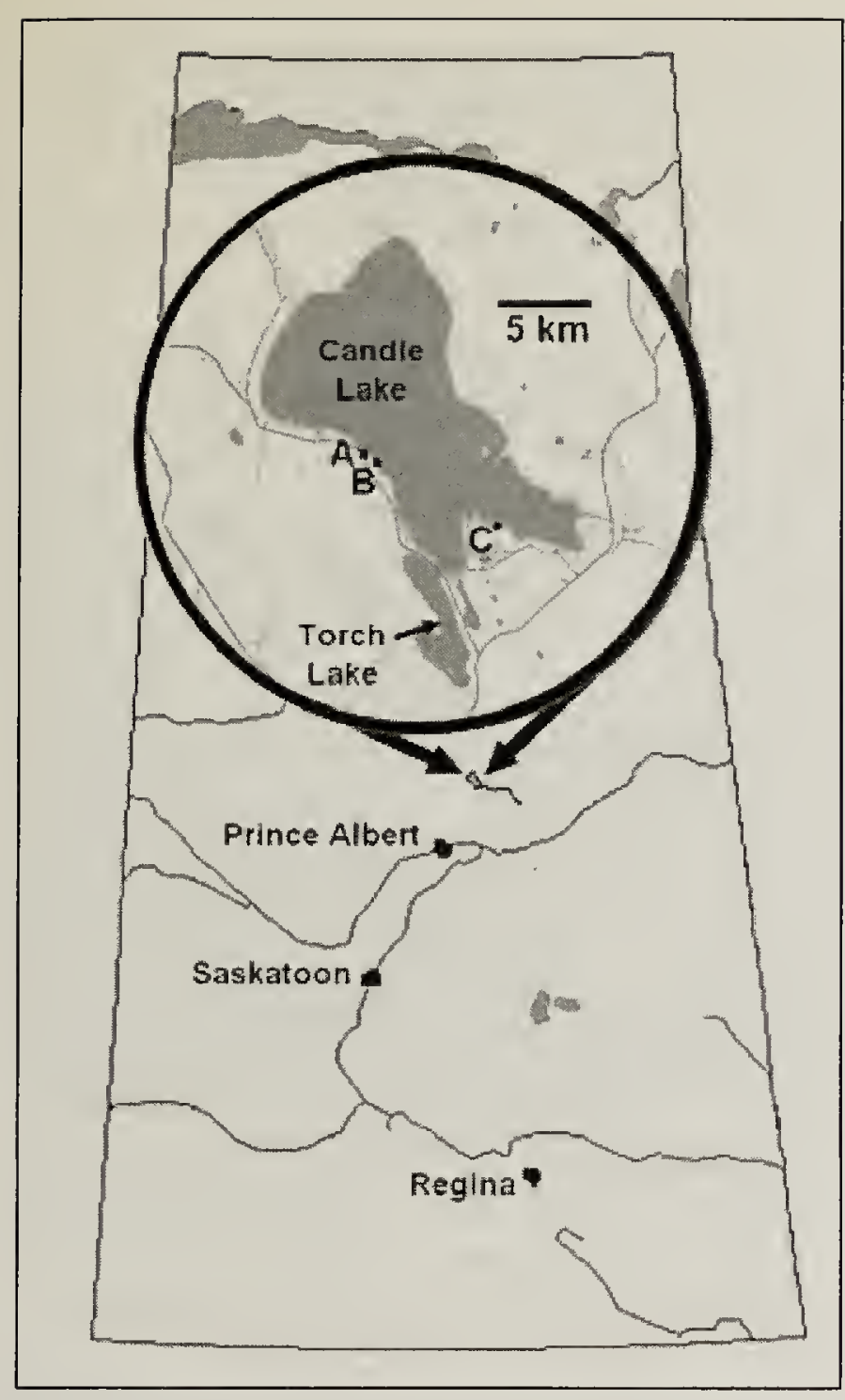

Figure 1: Map of Saskatchewan indicating location of Candle Lake. Inset indicates detail of the Candle Lake area and the three primary sampling locations.

logging, agricultural crops, livestock production and, recently, mining exploration.

Three primary study sites (A, B, and $C$ in Figure 1) that typified the shoreline habitats present in Candle Lake were selected.

Site A: Onechassa $\left(53^{\circ} 48^{\prime} 20^{\prime \prime} \mathrm{N}, 105^{\circ}\right.$ $20^{\prime} 31^{\prime \prime} \mathrm{W}$ ) is characterized by a lack of emergent and submerged vegetation. The substrate is small to large rocks embedded in sandy silt. The unprotected shoreline consists of wave-washed large rocks.

Site B: Sandy Bay Campground $\left(53^{\circ}\right.$ $48^{\prime} 03^{\prime \prime} \mathrm{N}, 105^{\circ} 19^{\prime} 43^{\prime \prime} \mathrm{W}$ ) is a small bay $200 \mathrm{~m}$ northwest of the provincial campground and beach. The substrate consists of areas of stable or shifting fine sand and silt with embedded rocks. An extensive bed of bulrushes (Scirpus validus) protects the shoreline from severe wave action. Clumps of cattails (Typha latifolia) and common reed grass (Phragmites communis) occur along the shoreline. Beds of stonewort (Chara $s p$.) develop during the summer. Submerged logs and fallen trees provide additional microhabitats. The shoreline ranges from rocky to sandy.

Site C: Northview Subdivision $\left(53^{\circ} 46^{\prime}\right.$ $16^{\prime \prime} \mathrm{N}, 105^{\circ} 13^{\prime} 46^{\prime \prime} \mathrm{W}$ ) has three general habitat areas; wetland, emergent vegetation and open water (Figure 2).

The wetland lies between the lakeshore and a stabilized sand bar. It is covered by dense aquatic vegetation consisting of bulrushes, cattails, sedges (Carex spp.), horsetail (Equisetum spp.) bur-reed (Sparganium sp.), sweet flag (Acorus calamus), arrowhead (Sagittaria cuneata) water-plantain (Alisma $s p$.), pondweeds (Potamogeton spp.), spike-rush (Eleocharis spp.) smartweed (Polygonum amphibium), mare's-tail (Hippuris vulgaris), buttercups (Ranunculus spp.), mint (Mentha arvensis), hornwort (Ceratophyllum demersum), watermilfoil (Myriophyllum sp.), bladderwort (Utricularia vulgaris), and other species. This vegetation forms a thick mat of entangled roots, rhizomes and decaying vegetation that floats approximately $20 \mathrm{~cm}$ above the lake bottom. During the spring and early summer this area was usually covered by water. At lower water levels, surface water disappears from some areas but the vegetation mat remains saturated. During windy conditions, lake swells can raise the water level in the wetland. 
Adjacent to the wetland is an area of thick emergent vegetation consisting primarily of sedges, cattails, bulrushes and horsetail. The substrate is predominantly sandy silt with some decaying vegetation and a few embedded rocks and submerged logs.

The remainder of the site is open water with sparse bulrush cover. The substrate consists of relatively stable, sand and silt with embedded rocks. The shoreline ranges from rocky to stabilized sandy silt. Wave action can be severe, causing erosion to exposed shorelines.

\section{Methods}

Qualitative sampling was conducted at approximately four-week intervals at each site during the ice-free season of 2001. Collections were made by sweeping a $20 \mathrm{~cm}$ diameter sieve or $30 \mathrm{~cm}$ D-framed aquatic dip net with $0.5 \mathrm{~mm}$ mesh openings through the water column, the emergent and submersed vegetation and along the bottom substrate. A rectangular $20 \mathrm{~cm}$ by $10 \mathrm{~cm}$ aquarium net with $0.1 \mathrm{~mm}$ mesh openings was used to sweep the water surface to collect exuviae (cast skins) and emerging adults. Aerial sweep net samples were taken along the shore at each site to collect adults. Aquatic samples were partially sorted in the field and preserved in $100 \%$ alcohol. Aerial samples were preserved in $75 \%$ alcohol in the field. In the lab, the material was sorted, identified and preserved in labeled vials with $75 \%$ alcohol.

In 2002, the lake sediment was sampled for mayflies using a 6-inch $\left(231 \mathrm{~cm}^{2}\right)$ Ekman grab. The lake was divided into three depth ranges 0 to 5 $\mathrm{m}, 5$ to $10 \mathrm{~m}$, and $>10 \mathrm{~m}$. On June 22, July 19 and August 22, three Ekman samples were taken in each of the three depth ranges and preserved in
$100 \%$ alcohol. In the lab, the samples were sieved through a $0.5 \mathrm{~mm}$ sieve and larvae were sorted from the residue, identified, enumerated and preserved in labeled vials in $75 \%$ alcohol. The data were combined for the three sampling dates.

To determine the timing and densities of emerging adults (\# emerging $/ \mathrm{m}^{2} /$ day) five, $0.49 \mathrm{~m}^{2}$, floating emergence traps (Figure 3) were randomly placed in each habitat type at Site C (Figure 2). ${ }^{4,8}$ Water depth was measured at each trap. Traps were operated continuously from June 3 to September 30 . Collections were made between 0900h and 1100h on a twoday, two-day, three-day schedule except for July 2 to July 3 when collections were made on July 2 after four days and July 3 after one day. Samples were preserved in $75 \%$ alcohol. Specimens were sorted, identified, sexed, enumerated and placed in labeled vials with $75 \%$ alcohol.

\section{Results}

Twelve species of mayfly belonging to six families were collected from Candle Lake during the study (Table 1).

Eleven species were collected by qualitative sampling methods. Eight species were collected from Site A, nine from Site $B$ and six from Site $C$. Four species, Caenis latipennis, Stenonema femoratum, Tricorythodes minutus, and Leptophlebia nebulosa were collected at all sites. Baetis $s p$. and Stenacron interpunctatum were collected only from site $A$ and $L$. cupida was collected only from Site $B$.

Four species were collected in the Ekman samples (Table 1). Callibaetis ferrugineus, Caenis latipennis and Ephemera simulans were collected only from the 0-5 m zone. Hexagenia limbata preferred the 5-10 $\mathrm{m}$ zone and 


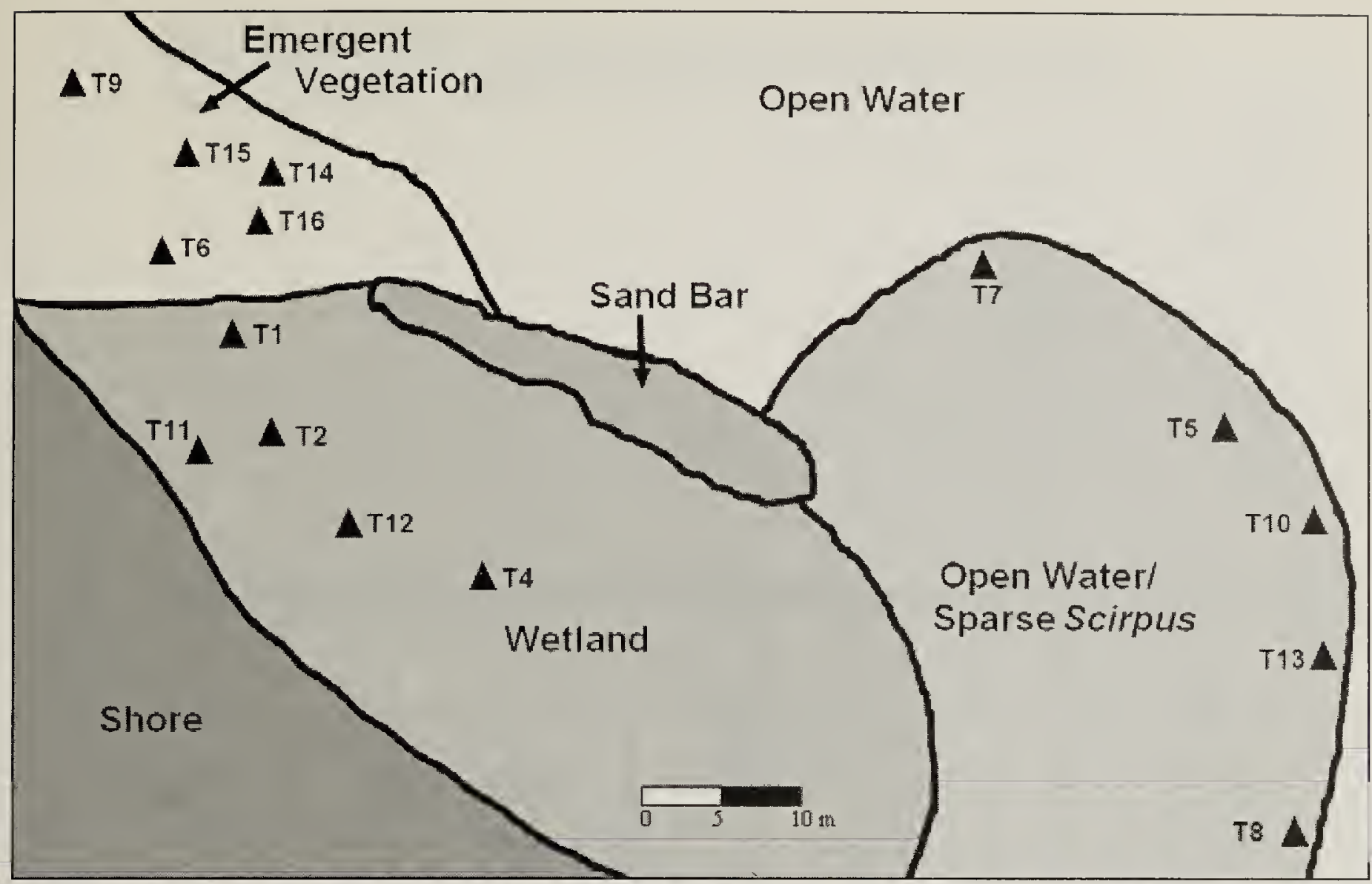

Figure 2: Detailed map of Site $C$ indicating vegetation zones and emergence trap (T\#) locations.

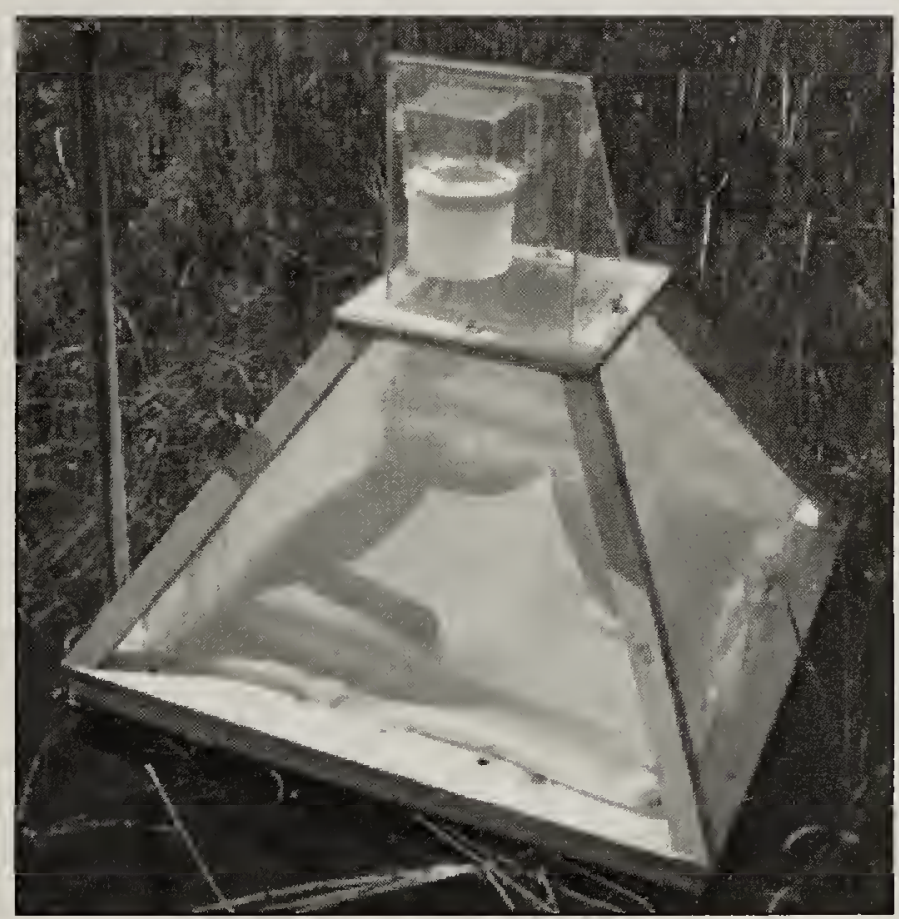

Figure 3: Floating emergence trap used at Site $C$.

was the only species collected below $10 \mathrm{~m}$.

The emergence traps placed at Site C collected 2165 mayflies belonging to eight species (Table 1) including Procloeon quaesitum, which had not been collected using other methods. Adult mayfly emergence occurred from June 3 to September 12, with most species emerging during July and August (Figure 4).

Average water depths at the emergence traps were $8 \mathrm{~cm}$ (range 0.64 to $12.9 \mathrm{~cm}$ ) for the wetland habitat, $20.4 \mathrm{~cm}$ (range 13.5 to $25.6 \mathrm{~cm}$ ) for the emergent vegetation habitat and 31.2 (range 23.9 to $35.9 \mathrm{~cm}$ ) for the open water habitat.

Leptophlebia nebulosa (Figure 5) accounted for $97.9 \%$ of the mayflies collected in the emergence traps (Table 1). Almost three-quarters, $74.5 \%$, of the adults of $L$. nebulosa were collected in the emergent vegetation zone. The wetland traps accounted for $25.4 \%$ of the total and the open water traps collected less than $0.1 \%$. These counts translate into an average yearly production of 644.5 adults $/ \mathrm{m}^{2}$ in the emergent vegetation, 219.6 adults $/ \mathrm{m}^{2}$ 


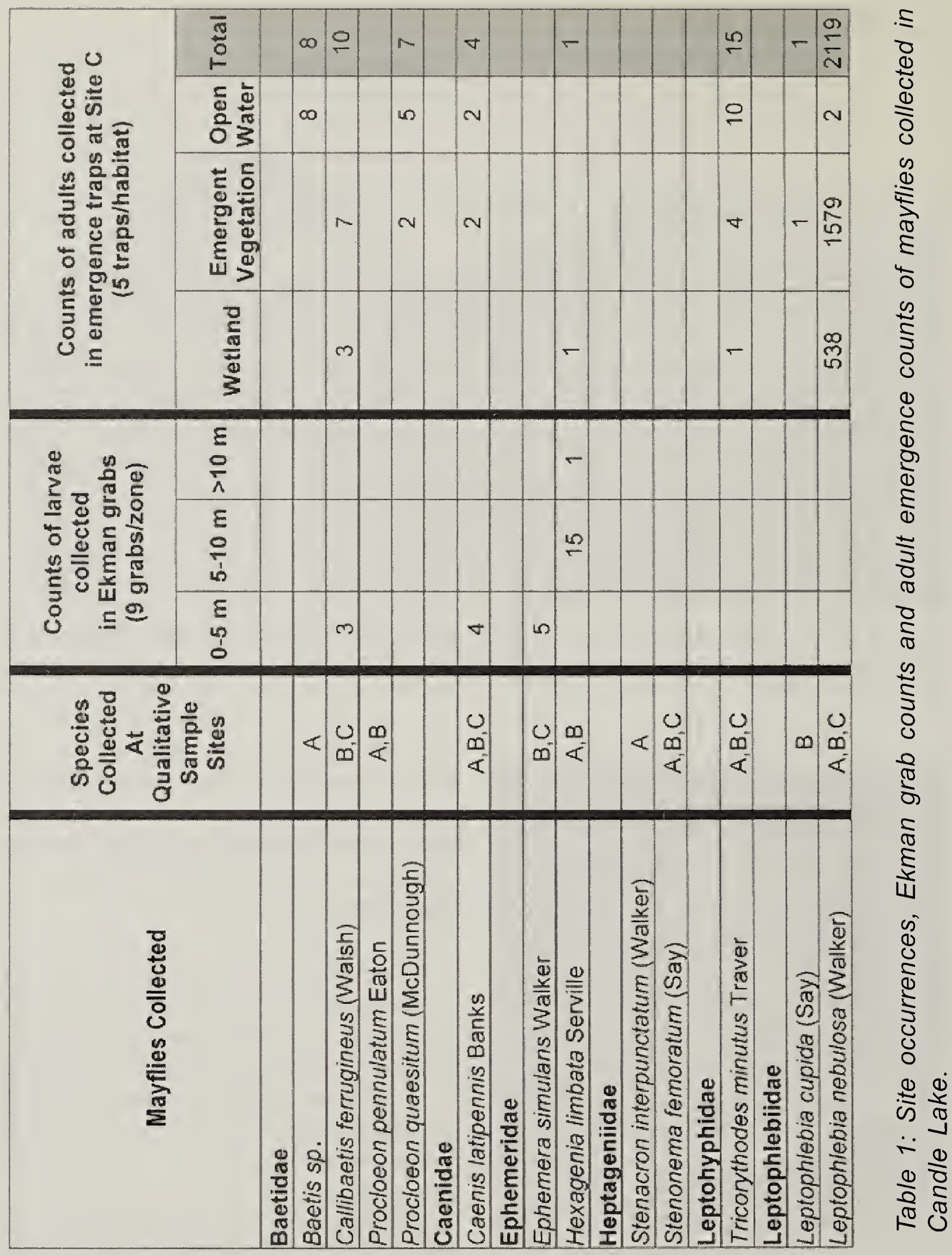

in the wetland zone and only 0.8 adults/ $\mathrm{m}^{2}$ in the open water zone.

Leptophlebia nebulosa was the earliest mayfly to emerge in the traps (Figure 4). It was first collected in June 5 samples and the last specimens were collected by July 12 (Figure 6 ). The largest emergence, 126.5 adults $/ \mathrm{m}^{2} /$ day, was recorded on June 21 . The sex ratio for $L$. nebulosa was 1.42:1 (1242 males: 877 females). There was no observed trend of either sex emerging earlier than the other.

\section{Discussion}

All the mayflies recorded from Candle Lake have previously been reported from Saskatchewan. ${ }^{3,16}$ Three species, Tricorythodes minutus, 


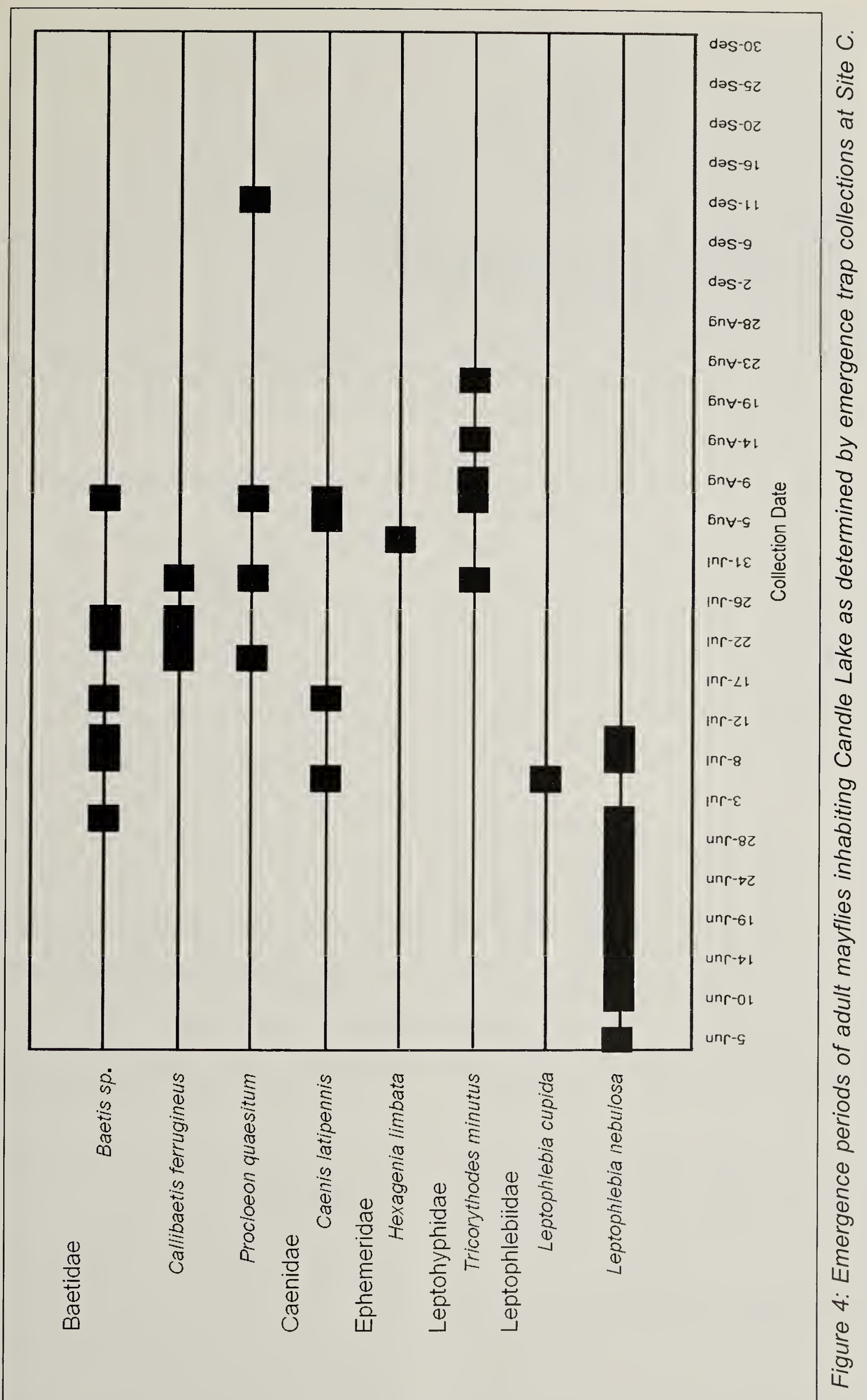




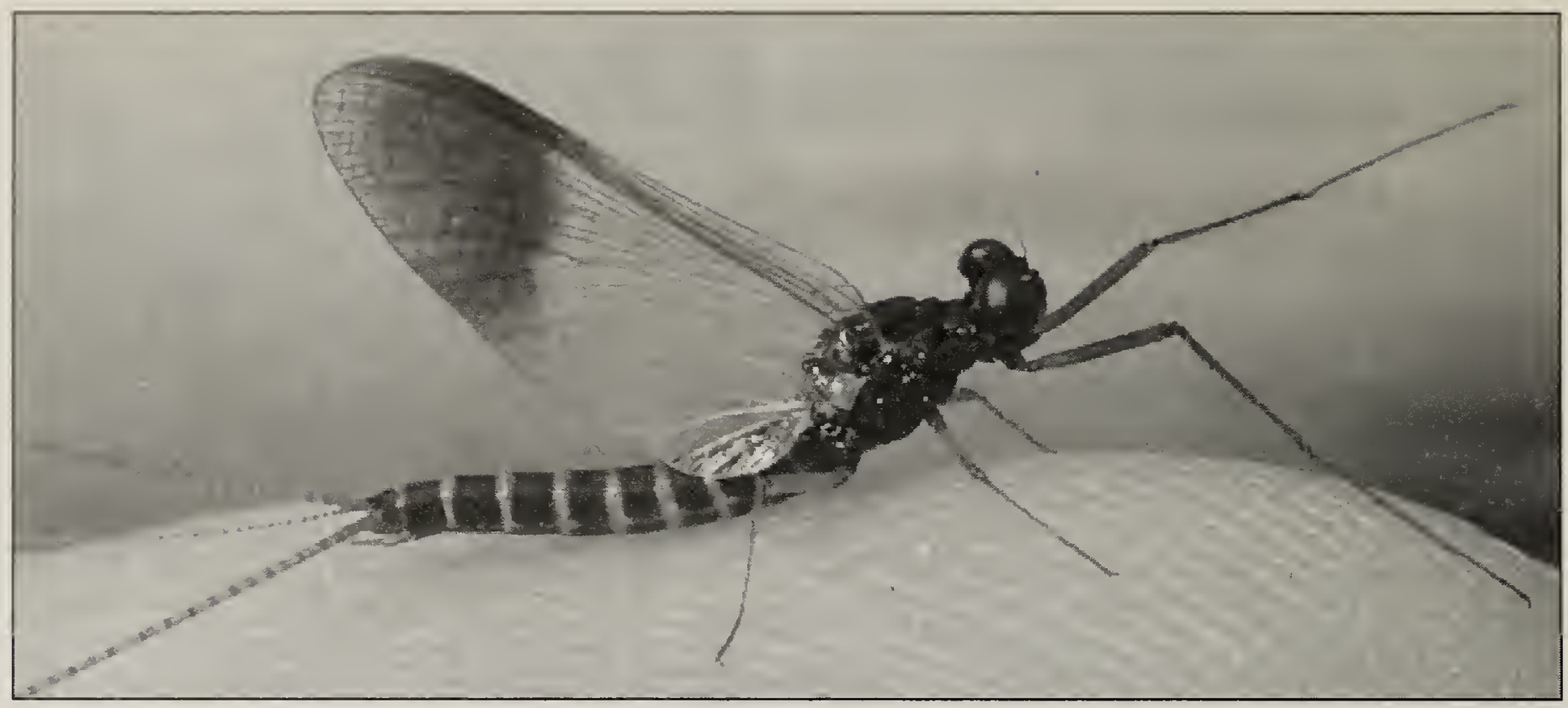

Figure 5: Adult male of Leptophlebia nebulosa sitting on fingertip. (Note enlarged eyes indicative of males.)

D. Parker

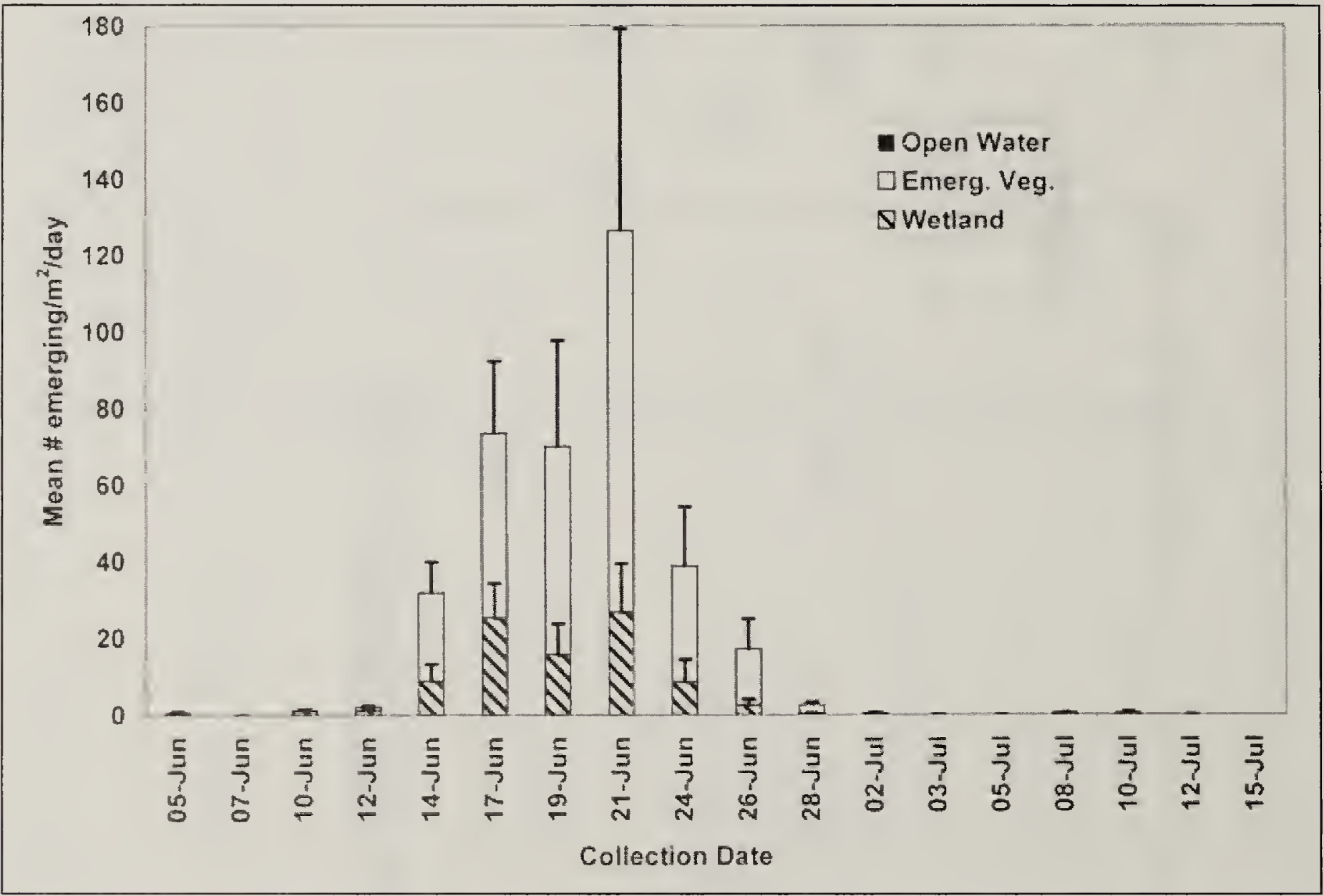

Figure 6: Adult emergence patterns of $L$. nebulosa as determined by emergence trap sampling at Site C. (Error bar +1 se)

Stenonema femoratum, and Stenacron interpunctatum are more typical of rivers and streams than of lakes. ${ }^{16}$ The presence of the bottom- sprawling $T$. minutus is unexpected, as it has previously been reported from only one other lake. ${ }^{3}$ S. femoratum and $S$. interpunctatum were mostly found associated with rocky wave-washed shorelines that provide microhabitats with enough wave-created current for them to survive.

Shallow water (littoral) zones are critical lake habitats. ${ }^{15,18}$ In lakes, the most abundant and diverse mayfly communities are associated with these habitats. ${ }^{1}$ This was the case in Candle Lake. The vegetation, fallen logs, and rocks subdivided the shallow water 
along the shore into numerous microhabitat types that could be exploited by mayfly larvae.

Hexagenia limbata was the only mayfly found in the deeper areas of the lake. Larvae of this species dig Ushaped tubes in soft substrates. The larva undulates its body and gills to create a water current through the tube to ventilate its gills and to filter feed. It has been recorded in low numbers to depths of $18 \mathrm{~m}$ and dissolved oxygen levels down to $1.0 \mathrm{ppm}$, which is unusual for mayflies. ${ }^{5}$

\section{Leptophlebia nebulosa emerged} from early June to mid-July, with the highest number of adults collected in mid-June. Absence of further emergence suggests it has only one adult emergence period each year (univoltine life cycle) in Candle Lake. A similar emergence pattern was recorded in a Michigan lake. ${ }^{9}$ The life cycle exhibited by $L$. nebulosa is a Uw type (seasonal univoltine winter cycle: the population overwinters in the larval stage). ${ }^{2}$ Unlike some species of mayflies that emerge directly from the water surface, mature larvae of $L$. nebulosa crawl out of the water onto an aerial substrate such as a plant stem or stick before the adult emerges. Larvae prefer vegetated habitats rather than sandy shores or wave-washed rocky shorelines. ${ }^{9}$ In the spring, the larvae migrate very close to shore prior to emergence. ${ }^{9}$ This preference for vegetated habitats was confirmed in Candle Lake by the large number of adults collected from the emergent vegetation and wetland traps compared to the sparsely vegetated open water area.

\section{Conclusions}

Candle Lake has a diversity of mayflies due to its variety of shallow water habitats, including wave-washed, rocky shallows that enable a number of species more typical of running water to successfully inhabit the lake. The mayfly fauna, except for Hexagenia limbata, was restricted to the shallower areas of the lake.

The numerically dominant mayfly, Leptophlebia nebulosa, has a univoltine life cycle with peak adult emergence occurring in mid-June. Its preference for shallow water habitats with emergent vegetation may make this species vulnerable to future developments that reduce the emergent vegetation in the lake. For this reason, it may be a good species for monitoring the effects of human activity on the lake. Larvae of $L$. nebulosa are likely a very important early spring food source for fish, and the adults for waterfowl and passerine birds. If human developments reduce populations of $L$. nebulosa through loss of habitat, this would likely reduce the food supply for many fish and birds at a critical time in their life cycles.

\section{Acknowledgments}

Funding for this research was through Saskatchewan Environment's Fish and Wildlife Branch. J. Halpin assisted with field collections and sample processing. J. Gabora, M. Hlasny, R. Hlasny, T. Hlasny, A. Nelson, C. Nelson, G. Nelson, T. Person and K. Willer assisted with emergence trap sampling.

1. BRITTAIN, J.E. 1982. Biology of mayflies. Annual Review of Entomology 27:119-147.

2. CLIFFORD, H.F. 1982. Life cycles of mayflies (Ephemeroptera), with special reference to voltinism. Quaestiones Entomologicae 18:15-90.

3. CORKUM, L.D. 1989. Habitat characterization of the morphologically similar mayfly larvae, Caenis and Tricorythodes (Ephemeroptera). Hydrobiology 179:103-109.

4. DAVIES, I.J. 1984. Chapter 6: Sampling aquatic insect emergence. In. Downing, J.A. and R.H. 
Rigler. (eds) A Manual on Methods for Assessment of Secondary Productivity in Freshwaters. Blackwell Scientific Publishing, Oxford. p. 161227.

5. EDMUNDS, G.F. Jr., S.L. JENSEN and L. BERNER. 1976. The Mayflies of North and Central America. University of Minnesota Press, Minneapolis, MN.

6. FUNG, K., B. BARRY and M. WILSON. (Ed.). 1999. Atlas of Saskatchewan. University of Saskatchewan, Saskatoon, SK.

7. LEHMKUHL, D.M. 1972. Change in the thermal regime as a cause of reduction of benthic fauna downstream of a reservoir. Journal of the Fisheries Research Board of Canada 29:1329-1332.

8. LESAGE, L. and A.D. HARRISON. 1979. Improved traps and techniques for the study of emerging aquatic insects. Entomological News 90:65-78.

9. LYMAN, F.E. 1955. Seasonal distribution and life cycles of Ephemeroptera. Annals of the Entomological Society of America 48:380-391.

10. MERRITT, R.W., K.W. CUMMINS and M.B.BERG (Ed.) 2008. An Introduction to the Aquatic Insects of North America. $4^{\text {th }} \mathrm{Ed}$. Kendall Hunt Publishing Company. Dubuque, IA.

11. PARKER, D.W. and D.M. LEHMKUHL. 1999. Diversity of aquatic macroinvertebrates in Saskatchewan. In: Thorpe, J., T.A. Steeves, and M. Gollop. (eds) Proceedings of the Fifth Prairie Conservation and Endangered Species Conference. Provincial Museum of Alberta,
Edmonton, Natural History Occasional Paper No. 24. p. 306-311.

12. RESH, V.H. and D.M. ROSENBERG. (Ed.) 1984. The Ecology of Aquatic Insects. Praeger Scientific, New York. NY.

13. ROSENBERG, D.M and V.H. RESH. (Ed.) 1993. Freshwater Biomonitoring and Benthic Macroinvertebrates. Chapman and Hall, New York. NY.

14. SCHINDLER, D.W., S.E. BAYLEY, B.R. PARKER, K.G. BEATY, D.R. CRUIKSHANK, E. J. FEE, E. U. SCHINDLER, and M.P. STAINTON. 1996. The effects of climatic warming on the properties of boreal lakes and streams at the Experimental Lakes Area, northwestern Ontario. Limnology and Oceanography 41:1004-1017.

15. THORP, J.H. and A.P. COVICH. (Ed.) 2001. Ecology and Classification of North American Freshwater Invertebrates. $2^{\text {nd }}$ Ed. Academic Press. New York. NY.

16. WEBB, J.M. 2002. The Mayflies of Saskatchewan. M.Sc. Thesis. University of Saskatchewan, Saskatoon, SK.

17. WEBB, J.M., D.W. PARKER, D.M. LEHMKUHL, and P. MCCAFFERTY. 2004. Additions and emendations to the mayfly (Ephemeroptera) fauna of Saskatchewan, Canada. Entomological News 115:213-218

18. WETZEL, R.G. 2001. Limnology, $3^{\text {rd }}$ Ed. Academic Press. San Diego. CA.

According to Frank Todd's 10,001 Titillating Tidbits of Avian Trivia, the Laysan Duck is the bird that declined to the lowest population level and subsequently recovered. "In 1930, the entire population was reduced to a single gravid female. An experienced biologist spent 16 days on the tiny island of Laysan, finding but a single pair of the ducks and a nest in which all the eggs were punctured by a Bristle-thighed Curlew. The drake subsequently disappeared, but the female retained sufficient semen in her oviduct to lay a fertile replacement clutch of eggs. Thus, the species owes it existence to that single persistent female. The endemic duck is wellestablished in captivity, and the wild population on Laysan Island was about 500 birds in the mid-1980s." 